\title{
Koagulacijske pretrage u veterinarskoj medicini
}

Andrea Tumpa* i Renata Barić Rafaj

\section{Sažetak}

Hemostaza je proces zaustavljanja krvarenja. Spontana hemostaza uključuje složene biokemijske mehanizme zgrušavanja krvi, regulirane interakcije između ozlijeđenog tkiva, stijenke krvnih žila i cirkulirajućih trombocita, prokoagulacijskih, antikoagulacijskih te fibrinolitičkih plazmatskih proteina. Proces hemostaze dijelimo na tri faze: primarna, sekundarna te fibrinoliza. Nefunkcionalna primarna hemostaza (trombocitopenija, kao glavni uzrok) za posljedicu ima usporeno i otežano stvaranje trombocitnog ugruška. U slučaju ozljede krv će izlaziti iz krvnih žila nekoliko sekundi ili minuta dok se ne formira stabilan sekundarni hemostatski ugrušak. U slučaju nefunkcionalne sekundarne hemostaze krvarenje se ne primjećuje izravno, već s vremenskim odmakom, najčešće nakon nekoliko minuta. Imajući na umu postajanje različitih faza hemostaze te različite aktivacije koagulacijskih kaskada, razvijene su i različite metode laboratorijskog mjerenja. Ovaj rad navodi i objašnjava koagulacijske pretrage koje se danas primjenjuju u veterinarskoj praksi. Opisana je metoda i svrha svake pretrage uz glavne primjedbe vezane uz uzorkovanje i moguće interferencije. Uzorkovanje krvi za koagulacijske pretrage osjetljivije je od uzorkovanja za ostale pretrage krvi. Nužno je izbjeći aktivaciju trombocita te se iz tog razloga idealnim uzorkovanjem smatra ono kod kojeg je krv vađena bez staze. Većina koagulacijskih pretraga kao uzorak koristi citratnu plazmu siromašnu trombocitima koja se dobiva nakon centrifugiranja (15 minuta na $2000 \mathrm{~g}$ ) pune krvi vađene uz antikoagulans 3-natrij-citrat-dihidrat (0,11 mol/L). Većina mjerenja osnovnih parametara hemostaze uključuje praćenje stvaranja ugruška (koaguluma), a prati se brzina i sposobnost ili nedostatak sposobnosti grušanja krvi. Danas su metode automatizirane, a vrijeme nastanka ugruška mjeri se elektromehaničkom ili foto-optičkom metodom. Osim mjerenja brzine nastanka ugruška moguće je mjerenje aktivnosti enzima i inhibitora koagulacije te mjerenje koncentracije pojedinih komponenti koagulacijskih kaskada i fibrinolize. U ovim slučajevima koriste se imunokemijske metode koje se temelje na specifičnoj reakciji antigen-antitijelo, pri čemu su od automatiziranih metoda u uporabi najčešće lateks-imunoturbidimetrije, a od ručnih metoda ELISA-e. U novije se vrijeme sve više nastoji ispitati poremećaj zgrušavanja u punoj krvi pomoću tromboelastografije. Za razliku od standardnih koagulacijskih testova, tromboelastografija evaluira kinetiku cijelog procesa zgrušavanja, od početnog

Andrea TUMPA*, mag. med. biochem., asistentica, (dopisni autor, e-mail: andrea_tumpa@hotmail. com), dr. sc. Renata BARIĆ RAFAJ, dipl. ing. med. biokem., redovita profesorica, Veterinarski fakultet Sveučilišta u Zagrebu, Hrvatska 
stvaranja ugruška, polimerizacije fibrina do konačne stabilnosti ugruška. $U$ ispitivanju uzroka krvarenja laboratorijskim pretragama procjenjuje se: rezistencija krvnih žila, broj i funkcija trombocita, unutrašnji i vanjski put zgrušavanja, mehanizam fibrinolize i djelovanje inhibitora zgrušavanja. Laboratorijska dijagnostika poremećaja hemostaze započinje izvođenjem globalnih pretraga. Globalne koagulacijske pretrage su najjednostavnije te istovremeno obuhvaćaju i vanjski i unutarnji put zgrušavanja, a u njih ubrajamo: vrijeme krvarenja, protrombinsko vrijeme, aktivirano parcijalno tromboplastinsko vrijeme, trombinsko vrijeme, broj trombocita i fibrinogen. Nakon globalnih pretraga, u svrhu postavljanja konačne dijagnoze, slijede specifične pretrage aktivnosti i funkcije trombocita, analiza trombocitnih antitijela, a po potrebi i mjerenja koncentracije i aktivnosti pojedinih faktora zgrušavanja i von Willebrandovog faktora te inhibitora zgrušavanja (antitrombin i protein C). Laboratorijski je moguće pratiti i tijek fibrinolize mjerenjem koncentracije razgradnih produkata fibrina i fibrinogena te D-dimera. S obzirom na složenost koagulacijskog sustava, laboratorijsko ispitivanje hemostaze potrebno je provesti u više stupnjeva, počevši od nekoliko globalnih pretraga te barem jedne specifične. Važno je naglasiti da ne postoji ni jedan test koji samostalno daje uvid u funkciju cjelokupnog sustava zgrušavanja.

Ključne riječi: hemostaza, koagulacija, trombociti, globalne pretrage, trombocitopenija

\section{Hemostaza}

Hemostaza (grč. haima krv, stasis zaustavljanje) proces je ili postupak zaustavljanja krvarenja. Spontana hemostaza uključuje složene biokemijske mehanizme zgrušavanja krvi, regulirane interakcije između ozlijeđenog tkiva, stijenke krvnih žila i cirkulirajućih trombocita, prokoagulacijskih i antikoagulacijskih te fibrinolitičkih plazmatskih proteina (Brooks i Catalfamo, 2013.).

Proces hemostaze dijelimo na tri faze: primarna i sekundarna hemostaza te fibrinoliza. Primarna hemostaza definirana je nastajanjem trombocitnog ugruška, a sastoji se od tri stadija. Prvi, vaskularni stadij uključuje kontrakciju krvne žile te započinje neposredno nakon ozljede. Slijedi endotelno-trombocitni stadij koji je karakteriziran sintezom i otpuštanjem von Willebrandovog faktora (vWF). Primarna hemostaza završava stadijem zgrušavanja krvi, odnosno uz prisustvo vWF dolazi do adhezije i agregacije trombocita na mjestu vaskularne ozljede te nastaje trombocitni agregat, tj. ugrušak. Sekundarna se hemostaza odnosi na reakcije koagulacijske kaskade, aktivacije sustava zgrušavanja te učvršćivanje trombocitnog ugruška fibrinskim vlaknima. Koagulacijska se kaskada sastoji od unutarnjeg i vanjskog puta zgrušavanja, a završava stvaranjem fibrinsko-stanične mrežice i stabilnog hemostatskog ugruška. Treća faza hemostaze jest fibrinoliza ili uklanjanje ugruška. Aktivni fibrinolitički enzim plazmin postupno razgrađuje zreli ugrušak kako bi se ponovno uspostavio normalan protok krvi (Brooks i Catalfamo, 2013., Bhaskar, 2016.).

Nefunkcionalna primarna hemostaza (trombocitopenija kao glavni uzrok) za posljedicu ima usporeno i otežano stvaranje trombocitnog ugruška. U slučaju ozljede krv će izlaziti iz krvnih žila nekoliko sekundi ili minuta dok se ne formira stabilni sekundarni hemostatski ugrušak. Kod takvih se poremećaja klinički mogu uočiti manja površinska krvarenja koja okružuju krvnu žilu, 
petehije, ekhimoze ili krvarenja na sluznicama (epistaksa, hematurija, melena i slično). U slučaju nefunkcionalne sekundarne hemostaze krvarenje se ne primjećuje izravno, već s vremenskim odmakom, najčešće nakon nekoliko minuta. Krvarenje je odgođeno zbog primarnog trombocitnog ugruška koji privremeno zatvara oštećenje na krvnoj žili. Ponovno istjecanje krvi posljedica je gubitka funkcije primarnog ugruška te rezultira nastankom obilnih krvarenja $\mathrm{u}$ obliku velikih hematoma ili krvarenja u tjelesne šupljine (Couto, 2014.).

\section{Metode koagulacijskih \\ pretraga}

Imajući na umu postajanje različitih faza hemostaze te različite aktivacije koagulacijskih kaskada razvijene su i različite metode laboratorijskog mjerenja. Većina mjerenja osnovnih parametara hemostaze uključuje praćenje stvaranja ugruška (koaguluma), prati se brzina i sposobnost ili nedostatak sposobnosti grušanja krvi te se stoga pretrage zbirno nazivaju koagulacijskim pretragama. Danas su metode automatizirane, a vrijeme nastanka ugruška mjeri se elektromehaničkom ili foto-optičkom metodom. Elektromehaničkom metodom detektira se stvaranje ugruška na temelju promjene viskoznosti ili na temelju promjene impendance sustava. Fotooptička metoda detekcije temelji se na promjeni intenziteta svjetlosti kojim se obasjava analizirana otopina. Ovisno o uređaju, mjeri se i postotak apsorbirane ili raspršene svjetlosti te se uporabom algoritama izračunava vrijeme stvaranja ugruška. Optičke metode podložne su interferencijama hemoglobina, bilirubina i lipemije, koji zbog svoje obojenosti ili visoke optičke gustoće ometaju pravilno mjerenje intenziteta svjetlosti. Ovim metodama služimo se pri mjerenju koagulacijskih parametara kao što su: protrombinsko vrijeme (PV), aktivirano parcijalno tromboplastinsko vrijeme (APTV), trombinsko vrijeme (TV) i fibrinogen (Fbg) (Miloš, 2010.).

Osim mjerenja brzine nastanka ugruška, moguće je i mjerenje aktivnosti pojedinog enzima i inhibitora. $U$ tu se svrhu primjenjuju kromogene metode, koriste se sintetski supstrati obilježeni kromoforom koji se oslobađa djelovanjem enzima koji mjerimo. Mjerenjem intenziteta nastale boje zaključuje se o stupnju aktivnosti enzima (Miloš, 2010.).

Uz aktivnost enzima moguće je i mjerenje koncentracije pojedinih komponenti koagulacijskih kaskada i fibrinolize. U ovom se slučaju koriste imunokemijske metode koje se temelje na specifičnoj reakciji antigen-antitijelo (Ag-At). Od automatiziranih metoda najčešća je lateks-imunoturbidimetrija, a od ručnih (engl. Enzyme-Linked Immunosorbent Assay). Lateks-imunoturbidimetrija temelji se na principu aglutinacije lateks čestica obloženih određenim antitijelom u prisustvu antigena. Time dolazi do promjene optičke gustoće analizirane otopine te se koncentracija analita izračunava iz algoritama proporcionalnosti kao i u foto-optičkim metodama. Temelj ELISA metode je uporaba dvaju antitijela, jednog koje sudjeluje $\mathrm{u}$ reakciji ispitivanog antigena, a drugog koje je obilježeno kromoforom i veže se na stvoreni kompleks Ag-At $u$ otopini. Pri tome dolazi do aktivacije ili otpuštanja kromofora te se detekcija vrši kao kod kromogenih metoda. Ovim se metodama kvalitativno i kvantitativno određuje nedostatak pojedinih faktora ili inhibitora zgrušavanja (Miloš, 2010.).

U novije se vrijeme sve više nastoji ispitati poremećaj zgrušavanja u punoj krvi pomoću tromboelastografije. Za razliku od standardnih koagulacijskih testova, tromboelastografija evaluira kinetiku cijelog procesa zgrušavanja, od početnog stvaranja ugruška, polimerizacije fibrina do konačne stabilnosti ugruška. Ti dinamički testovi 
daju sliku međusobne interakcije plazme, krvnih stanica i trombocita i odraz su situacije in vivo, što standardne koagulacijske pretrage ne omogućuju. Ovom analizom dobiva se grafički prikaz različitih faza zgrušavanja krvi, a rezultati se prikazuju u obliku krivulje koja se naziva tromboelastogram. Tako se pomoću analizatora funkcije trombocita može predoperativno otkriti poremećaj u funkciji trombocita, dijagnosticirati stečene ili nasljedne trombocitopatije, otkriti von Wilebrandovu bolest (vWB) i pratiti djelotvornost terapije acetilsalicilnom kiselinom (Mallett i Cox, 1992., Otto i sur., 2000., Ao i sur., 2001., Wiinberg i sur., 2005.).

\section{Uzorak u koagulacijskim pretragama}

Uzorkovanje krvi za koagulacijske pretrage osjetljivije je od uzorkovanja za ostale pretrage. Nužno je izbjeći aktivaciju trombocita pa se iz tog razloga idealnim uzorkovanjem smatra ono kod kojeg je krv vađena bez staze. Ukoliko se koristi podveza, ona mora biti što kraća, manje od minute, a potrebno je osigurati i dovoljnu brzinu protoka krvi kako bi se izbjeglo oslobađanje tkivnih faktora zgrušavanja. Uz to je iznimno bitna i epruveta u koju se vadi krv. Epruvete (spremnici) moraju biti od neaktivirajućeg materijala poput polipropilenske plastike ili silikoliziranog stakla, a moraju biti ispunjene i odgovarajućim antikoagulansom. Nužno je, već pri vađenju krvi miješanje i okretanje spremnika te obvezno nježno izokretanje spremnika 3 do 6 puta nakon vađenja kako bi se krv dobro izmiješala s antikoagulansom (Nikolac i sur., 2012.).

Većina koagulacijskih pretraga kao uzorak koristi citratnu plazmu siromašnu trombocitima. Za dobivanje takve plazme koriste se komercijalni spremnici koji sadrže antikoagulans 3-natrij-citrat-dihidrat $(0,11 \mathrm{~mol} / \mathrm{L}), \quad u$ puferiranom ili nepuferiranom obliku.
Antikoagulanti učinak temelji se na vezivanju iona kalcija iz plazme čime se onemogućava inicijacija zgrušavanja. Potreban omjer krvi i antikoagulansa je 9 : 1. U slučajevima kada se u spremniku ne nalazi dovoljna količina krvi, moguće je znatno produljenje vremena koagulacije, osobito u mjerenju APTV-a. Takvi uzorci za koagulacijske analize nisu prihvatljivi. Također, neprimjeren je i uzorak kojem je vrijednost hematokrita za $10 \%$ veća od njegove gornje referentne vrijednosti iako je volumen krvi u spremniku odgovarajući. Naime, zbog povećanog hematokrita, udio plazme je manji pa je stoga omjer plazme i antikoagulansa promijenjen (Miloš, 2010., Funk i sur., 2012., Mischke, 2017.).

Spremnik se s uzorkom dostavlja $\mathrm{u}$ laboratorij na sobnoj temperaturi (kako bi se izbjegla aktivacija trombocita) $u$ što kraćem vremenu, idealno je u manje od sata. Slijedi centrifugiranje uz silu od 2000 g kroz 15 minuta kako bi se dobila plazma siromašna trombocitima. Plazma se odvaja od stanica te je spremna za analizu ili pohranu. Ovisno o pretragama, plazma se može koristiti unutar 1, 4 i 24 sata ili se zamrzava na $-20{ }^{\circ} \mathrm{C}$ te se koristi unutar 3 mjeseca. Najosjetljiviji su faktori pet (FV) i osam (FVIII) te protein S čije se analize moraju odraditi u što kraćem periodu. Ukoliko je nužno vršiti analize funkcije trombocita, plazma se mora analizirati unutar 4 sata (Miloš, 2010., Funk i sur., 2012.).

Neka su istraživanja dokazala veću stabilnost uzoraka, čak i tijekom 48 sati nakon uzorkovanja. Minimalne su razlike $\mathrm{u}$ rezultatima većine koagulacijskih testova s obzirom na skladištenje uzorka citrirane plazme siromašne trombocitima na sobnoj temperaturi ili pri $8{ }^{\circ} \mathrm{C}$. Poslije 8 i 24 sata, jedina značajna razlika je pad koncentracije fibrinogena u uzorku plazme psa skladištenom na sobnoj temperaturi i na $8{ }^{\circ} \mathrm{C}$. Von Willebrandov faktor $\mathrm{u}$ plazmi psa također je stabilan tijekom prvih 48 sati skladištenja 
pri 4 ili $22{ }^{\circ} \mathrm{C}$. Nije poznato jesu li mačja plazma i patološki uzorci jednako stabilni u ovakvim uvjetima skladištenja (Mischke, 2017.).

Lipemični, hemolitični i ikterični uzorci nisu primjereni za koagulacijske pretrage. Osim što prouzroče interferencije $\mathrm{u}$ detekciji pri određenim valnim duljinama, $u$ hemolizi se oslobađaju prokoagulacijski i antikoagulacijski faktori koji u potpunosti mijenjaju rezultate analize. Ukoliko stupanj lipemije i ikterije nije velik, njihovu interferenciju moguće je ublažiti, čak i izbjeći promjenom valnih duljina detekcije ili primjenom mehaničke metode detekcije, no hemolizirani uzorak uvijek je neprimjeren, neovisno o stupnju hemolize (Miloš, 2010., Funk i sur., 2012.).

\section{Koagulacijske pretrage}

$\mathrm{U}$ ispitivanju uzroka krvarenja laboratorijskim pretragama procjenjuje se: rezistencija krvnih žila, broj i funkcija trombocita, unutarnji i vanjski put zgrušavanja, mehanizam fibrinolize i djelovanje inhibitora zgrušavanja (Miloš, 2010.).

Laboratorijska dijagnostika poremećaja hemostaze započinje izvođenjem globalnih pretraga. Globalne koagulacijske pretrage najjednostavnije su i istovremeno obuhvaćaju i vanjski i unutarnji put zgrušavanja. U njih ubrajamo vrijeme krvarenja (VK), PV, APTV, TV, broj trombocita (Trc) i Fbg (Miloš, 2010.). U svim globalnim pretragama određuje se aktivnost parametara zgrušavanja i fibrinolize. Rezultati globalnih pretraga unutar referentnog intervala ne isključuju mogućnost postojanja blagog nedostatka nekog od faktora zgrušavanja (Kitchen i Makris, 2009.). Nakon globalnih pretraga, u svrhu postavljanja konačne dijagnoze, slijede specifične pretrage aktivnosti i funkcije trombocita, a zatim po potrebi i mjerenja koncentracije i aktivnosti pojedinih faktora i inhibito- ra zgrušavanja. S obzirom na složenost samog sustava, laboratorijsko ispitivanje sekundarne hemostaze kod sumnje na poremećaj zgrušavanja potrebno je provesti u nekoliko stupnjeva. Važno je naglasiti da ne postoji niti jedan test koji daje uvid u funkciju cjelokupnog sustava zgrušavanja (Miloš, 2010.).

\section{Globalne pretrage hemostaze \\ Broj trombocita}

Ukupan broj trombocita sastavni je parametar hematološke pretrage krvne slike. S obzirom na ulogu trombocita u zgrušavanju krvi, Trc je ujedno i prva laboratorijska pretraga $u$ procjeni poremećaja hemostaze. Ukupan broj trombocita odmah ukazuje na moguće krvarenje u organizmu pri čemu trombocitopenija može biti jedini ili jedan od uzroka krvarenja. Lažno nizak Trc relativno je česta pojava u laboratorijskim nalazima, osobito kod analiza mačje krvi (Tasker i sur., 1999., Granat i sur., 2011.), zbog čega je uvijek nužna provjera. Istinitost trombocitopenije potvrđuje se u razmazu periferne krvi uz May-Gruenwald-Giemsa bojenje te korekcijske faktore kako bi se isključila trombocitopenija uslijed sljepljivanja trombocita (Payne, 1985., Brooks i Catalfamo, 2013.).

Trombociti se danas broje automatiziranim hematološkim brojačima, koji osim Trc-a mogu dati i još neke parametre poput veličine, odnosno volumena trombocita. Princip brojenja zasniva se na jednoj od metoda, elektromehaničkoj metodi promjene impedancije ili na optičkoj metodi brojenja temeljem raspršenja svijetlosti. Metoda impedancije, u literaturi poznata i kao Coulterovo načelo, temelji se na mjerenju promjene električnog otpora (impedancije) nastalog prolaskom krvnih stanica kroz mjerni otvor, pri čemu svaka analizirana krvna stanica daje jedan mjerni signal, a veličina nastalog signala razmjerna je volumenu stanice (Briggs i sur., 2007.). Ograničenje impedancijske 
metode je interferencija drugih stanica ili čestica slične veličine, kao što su ekstremno mikrocitni eritrociti ili fragmenti eritrocita. U analizama mačje krvi, zbog sličnosti u veličini trombocita i eritrocita te sljepljivanja trombocita, pogreške u prebrojavanju su učestalije nego u drugih vrsta (Tasker i sur., 1999., Granat i sur., 2011.).

Optička metoda brojenja trombocita novija je i preciznija. Temelji se na mjerenju raspršenja laserske svjetlosti koja obasjava pojedinu stanicu u uzorku. Raspršenje svjetla svakog analiziranog trombocita mjeri se pod definiranim kutom, a nastali svjetlosni signali se prevode u električne signale koji daju podatak o broju i volumenu trombocita. Metoda uklanja glavne nedostatke metode impedancije zahvaljujući činjenici da je refraktorni koeficijent specifičan za svaki tip stanica te je ovom metodom brojenja moguće razlučiti velike trombocite od trombocita normalne veličine, ali i fragmente eritrocita i ekstremno mikrocitne eritrocite (Kunicka i sur., 2000., Briggs i sur., 2007., Briggs i Machin, 2012.).

Za mjerenje Trc-a potrebna je krv uzeta $\mathrm{s}$ antikoagulansom etilendiaminotetraoctena kiselina u obliku kalijeve soli (KEDTA) koji je standardizirani uzorak za hematološku analizu. U slučajevima pseudotrombocitopenije, gdje dolazi do sljepljivanja trombocita, potrebno je ponoviti uzorkovanje uz citrat kao antikoagulans (ili uz kombinaciju EDTA s teofilinom, adenozinom i dipiridamolom - CTAD spremnici) te ponoviti pretragu Trc (Granat i sur., 2011.).

\section{Trombinsko vrijeme}

Trombinsko vrijeme jednostavna je pretraga kojom se promatra proces pretvorbe Fbg u fibrin. Pretraga se temelji na dodavanju trombina $u$ uzorak citratne plazme te mjerenju vremena potrebnog za stvaranje ugruška (Triplett, 2000.). Detekcija ugruška vrši se elektromehaničkom ili foto-optičkom metodom. Ovom metodom preskaču se svi koraci koji fiziološki dovode do nastanka trombina pa TV-om ne mjerimo ni vanjski ni unutarnju put zgrušavanja već nam TV govori isključivo o aktivnosti Fbg-a i prisustvu razgradnih produkata Fbg-a i fibrina (FDP). Na mjerenje TV-a utječe prisustvo heparina, stoga nije primjenjiv kod pacijenata na heparinskoj terapiji. Ukoliko je pretraga modificirana te se umjesto trombina dodaje reptilaza (trombinu slična proteaza iz zmijskog otrova) TV prestaje biti osjetljivo na heparin. Trombinsko je vrijeme produženo pri niskim koncentracijama Fbg-a, kod disfibrinogenije (sinteza Fbg-a postoji, ali Fbg nije funkcionalno aktivan), u prisustvu velikog broja razgradnih produkata Fbg-a (inhibiraju polimerizaciju) te $u$ prisustvu heparina zbog njegove interferencije (Adcock i sur., 2006.).

\section{Protrombinsko vrijeme}

Prekretnicu u laboratorijskoj dijagnostici napravio je $1935 \mathrm{~g}$. Armand J. Quick uvođenjem prvog specifičnog testa kojeg je nazvao protrombinskim vremenom, a koje se i danas ponekad naziva i Quickovim vremenom. Protrombinsko vrijeme je jedan od osnovnih laboratorijskih testova probiranja koji se i najviše koristi, a riječ je o vremenu nastanka ugruška nakon dodatka kalcija i tkivnog faktora tromboplastina. Uzorak za analizu je citratna plazma siromašna trombocitima, a stabilna je tijekom $24 \mathrm{~h}$ i na temperaturama $2-4{ }^{\circ} \mathrm{C}$, a na sobnoj temperaturi 18 - $25^{\circ} \mathrm{C}$ (Mischke, 2017.).

Osnovni princip testa počiva na Morawitzovoj klasičnoj teoriji zgrušavanja krvi, vrijeme zgrušavanja plazme nakon rekalcifikacije (dodatka kalcija) razmjerno je koncentraciji protrombina, pod uvjetom da je adekvatna količina Fbg-a prisutna u plazmi. Jedina nepoznata vari- 
jabla u testu je protrombin, s obzirom na to da se dodaje točno određena (fiksna) količina tromboplastina i kalcija, a koncentracija Fbg je dovoljna za optimalno zgrušavanje. Pretraga upućuje na mjeru aktivnosti faktora vanjskog puta zgrušavanja i biološku aktivnost faktora II, V, VII, X i Fbg-a (Miloš, 2010.).

Najveće kliničko značenje pretrage je detektiranje urođenog nedostatka faktora vanjskog puta zgrušavanja što se očituje produženim vrijednostima PV-a zbog smanjene aktivnosti faktora, obično samo jednog od njih. Produženo PV ukazuje na tešku deficijenciju faktora zgrušavanja, zbog toga što njihova aktivnost mora pasti na svega $30 \%$ normalne vrijednosti kako bi se uočilo produženo vrijeme zgrušavanja. Osim urođenog, detektira se i stečeni nedostatak faktora vanjskog puta kao posljedica otrovanja (mišomor), uporabe određenih lijekova (antagonisti vitamina $\mathrm{K}$ ), bolesti jetre ili diseminirane intravaskularne koagulacije (DIK). Zbog praćenja faktora II, VII i X koji su ovisni o vitaminu K, pretraga je i konvencionalni test za utvrđivanje statusa vitamina K. U slučajevima nedostatka vitamina $\mathrm{K}$, faktori koji o njemu ovise nisu funkcionalni, njihova aktivnost je smanjena te je vrijeme zgrušavanja produženo, odnosno vrijednosti PV-a su veće od referentnih (Brooks i Catalfamo, 2013., Mischke, 2017.).

$\mathrm{Na}$ točnost rezultata PV-a najviše utječu predanalitičke pogreške, prije svega kompresija duža od 1 minute, smanjen omjer krv/antikoagulans, nepuferirani citrat niže koncentracije te hemoliza. Osim kompresije, sve navedene predanalitičke pogreške daju lažno skraćene vrijednosti PV-a. S obzirom na to da je hemolitičan uzorak uvijek neprimjeren za koagulacijske analize, od navedenih pogrešaka ta je najveća te obvezno zahtijeva ponavljanje uzorkovanja i mjerenja (Miloš, 2010.).

\section{Aktivirano parcijalno tromboplastinko vrijeme}

Aktiviranim parcijalnim tromboplastinskim vremenom procjenjuju se poremećaji unutarnjeg i zajedničkog puta zgrušavanja, a samo faktori VII i XIII nisu uključeni u pretragu. Test je osjetljiviji od aktiviranog vremena zgrušavanja (ACV) te na njega ne utječu primarni hemostatski poremećaji. Vrijednosti APTV-a su produžene ako je aktivnost faktora manja od $30 \%$ ili ako u plazmi postoje antitijela na pojedine faktore. Analiza APTV-a započinje inkubacijom plazme s optimalnom količinom fosfolipida i aktivatora kontaktnog sustava, nakon koje slijedi dodavanje kalcija kako bi se aktivirala koagulacijska kaskada te se stvorio fibrinski ugrušak (Dudek i sur., 2011.).

S obzirom na to da APTV-om mjerimo i aktivnost FV i FVIII koji su izrazito osjetljivi i brzo propadaju, stabilnost uzorka za analizu znatno je kraća od uzoraka za druge pretraga. Uzorak je citratna plazma siromašna trombocitima, a odvojena plazma stabilna je do $4 \mathrm{~h}$ na temperaturama $2-4{ }^{\circ} \mathrm{C}$ i $18-25^{\circ} \mathrm{C}$. U slučajevima kada nije moguće napraviti analizu $\mathrm{u}$ tom periodu, plazma se alikvotira i zamrzava. Ukoliko je pacijent na terapiji heparinom, uzorak je nužno dva puta centrifugirati i odvojiti plazmu od stanica unutar jednog sata od uzorkovanja. Takva heparinizirana citratna plazma stabilna je tijekom 4 sata (Funk i sur., 2012.).

Mjerenjem APTV-a može se postaviti dijagnoza nasljednih sklonosti krvarenju uslijed nedostatka ili deficita faktora VIII, IX, XI, XII (hemofilije i vWB) pri čemu je vrijednost APTV-a produžena, dok su vrijednosti PV-a i TV-a unutar referentnog intervala (Miloš, 2010.).

Pogreške pri mjerenju APTV-a uglavnom su predanalitičke prirode, najčešća među njima je odgođeno vrijeme analize. Od interferencija u analizi najčešća je interferencija heparina koji je dan u terapeutske svrhe. Njegovo 
prisustvo dovodi do produženog vremena zgrušavanja te se na to pri interpretaciji nalaza mora obratiti pozornost (Funk i sur., 2012.).

\section{Aktivirano vrijeme zgrušavanja}

Aktivirano vrijeme zgrušavanja je brza, jednostavna i jeftina pretraga za dijagnostiku poremećaja unutarnjeg i zajedničkog puta zgrušavanja. Može se koristiti kao pomoć $u$ detekciji koagulopatija kao posljedice zmijskog otrova, nedostatka vitamina $\mathrm{K}$, hemofilije i DIK-a. Uzorak za analizu je puna krv koja se miješa s aktivatorom zgrušavanja, obično diatomaceoznom zemljom ili kaolinom s ciljem aktivacije faktora XII (Ruotsalo i Margo, 2009., See i sur., 2009.). Zgrušavanje se može mjeriti mehaničkom ili elektrokemijskom metodom. Pretraga nije osjetljiva na mala smanjenja faktora zgrušavanja. Potreban je nedostatak faktora od čak 95 \% (Ruotsalo i Margo, 2009.). See i sur. (2009.) odredili su referentne vrijednosti za mačke 55 - $85 \mathrm{~s}$ te 55 - 80 s za pse. Pretraga nije specifična jer na produljenje ACV-a utječu različita stanja poput trombocitopenije, disfunkcije trombocita, hematokrit i aktivnost plazmatske proteaze (Brooks i Catalfamo, 2013.).

\section{Vrijeme krvarenja}

Vrijeme krvarenja je vrijeme potrebno za potpuni prestanak krvarenja na mjestu incizije kože. Ovim se in vivo testom ispituje $\mathrm{u}$ kojoj mjeri trombociti reagiraju sa stijenkom krvne žile te se tako otkrivaju i kvalitativni poremećaji trombocita (Adcock i sur., 2006.).

$\mathrm{U}$ veterinarskoj medicini test je modificiran, incizija se vrši na bukalnoj sluznici te se stoga naziva vrijeme krvarenja bukalne sluznice (BMBV). Produženo BMBV ( $>4$ minute) zapaža se u pacijenata sa smanjenim brojem trombocita ili $u$ pacijenata $s$ fiziološkim vrijednostima trombocita $\mathrm{s}$ poremećajima agregacije trombocita i von Willebrandovom bolesti. Ponekad je BMBV produljen $i \mathrm{u}$ pacijenata $s$ anemijom i hiperproteinemijom. Iako je test "screening" test poremećaja primarne hemostaze $u$ pasa i mačaka, danas se rijetko koristi zbog nedovoljne standardizacije, ovisnosti o temperaturi, nepouzdanosti, male osjetljivosti i specifičnosti te nepostojanja stvarnih referentnih vrijednosti (Brooks i sur., 2011., Brooks i Catalfamo, 2013.).

\section{Fibrinogen}

Metoda određivanja fibrinogena modifikacija je Claussove metode. Uzorku plazme dodaje se trombinski reagens u suvišku što dovodi do pretvorbe Fbg u fibrin. Mjeri se vrijeme zgrušavanja u sekundama pri čemu je brzina stvaranja ugruška razmjerna koncentraciji Fbg-a u plazmi. Analizator automatski preračunava izmjereno vrijeme (aktivnost Fbg-a) u koncentraciju (g/L) na temelju kalibracijske krivulje dobivene komercijalnim kalibracijskim plazmama. Uzorak za analizu je citratna plazma, a interferiraju hemoliza i lipemija. Visoke doze heparina i FDP-a mogu utjecati na rezultate analize (Adcock i sur., 2006., Funk, 2012.). Osim aktivnosti, moguće je izmjeriti točnu koncentraciju Fbg-a imunokemijskim metodama. Najčešće je riječ o nefelometriji te se stoga mora obratiti pozornost na lipemične i zamućene uzorke koji nisu povoljni za analizu (Adcock i sur., 2006.).

\section{Specifične pretrage hemostaze}

\section{Trombotest - PIVKA test}

Protrombinski kompleks obuhvaća prokoagulacijske faktore zgrušavanja II (protrombin), VII, IX i X te dva proteina s antikoagulacijskim djelovanjem, protein $\mathrm{C}$ i protein $\mathrm{S}$, koji se sintetiziraju $\mathrm{u}$ stanicama parenhima jetre kao fiziološki inaktivni prethodnici. Njihovo zajedničko svojstvo je da imaju 9 - 12 ostataka glutaminske kiseline na $\mathrm{N}$-terminalnom dijelu molekule, koji se moraju 
transformirati $\mathrm{u} \gamma$-karboksiglutaminsku kiselinu kako bi postali funkcionalno aktivni. Aktivnost je ovisna o vitaminu K koji je odgovoran za posttranslacijsku karboksilaciju. U slučaju nedostatka vitamina KvWB izostaje karboksilazna aktivnost pa stanice jetre oslobađaju nefunkcionalne proteine koji se nazivaju PIVKA (engl. proteins induced by vitamin K absence) (Miloš, 2010.).

Trombotest, često nazivan i PIVKA test, načelno je varijacija pretrage PV-a. Za razliku od PV-a koristi se razrijeđena plazma uz specijalni tromboplastin $\mathrm{s}$ promijenjenom specifičnosti. Ideja trombotesta bila je specifična detekcija pojave PIVKA proteina te izravno povezivanje s uzrokom-manjkom vitamina K. Međutim, s vremenom je dokazano da gotovo ne postoji nikakva razlika u rezultatima PV-a i PIVKA testa (Rozanski, 1999.). Oboje prate vanjski put zgrušavanja te, iako PIVKA test uključuje sve faktore ovisne o vitaminu $\mathrm{K}$, a PV ne detektira FIX, utjecaj tog jednog faktora, nije dovoljan za znatniju razli$\mathrm{ku}$ rezultata ovih pretraga. $\mathrm{S}$ obzirom na veću cijenu provođenja PIVKA testa te činjenicu da test ne daje specifične rezultate za PIVKA proteine, danas je uglavnom $u$ potpunosti zamijenjen PV-om koji je dostupniji i standardiziran (Owren, 1959., Rozanski, 1999.). Za specifičnu detekciju protrombinskog kompleksa i PIVKA proteina nužna je uporaba imunoloških metoda za mjerenje koncentracije i biološke aktivnosti FII, VII, IX i X te proteina C i S (Miloš, 2010.). Trombotest je bio definiran i kao specifičan i osjetljiv kod sumnje na intoksikaciju rodenticidima, no rezultati produženog vremena koagulacije jednaki su kao i kod drugih stečenih koagulopatija (posljedice neoplazija, bolesti jetre, hemolitičke anemije i drugih) te se danas PIVKA test rijetko koristi, čak i u tu svrhu (Rozanski, 1999.).

Uzorak za analize razrijeđena je citratna plazma siromašna trombocitima.
Zbog osjetljivosti ispitivanih faktora, analize se moraju odraditi unutar 4 sata od vađenja krvi ili se odmah po vađenju centrifugiraju dva puta, zatim se plazma alikvotira i zamrzava na $-24{ }^{\circ} \mathrm{C}$ (Rozanski, 1999., Funk i sur., 2012.).

\section{Određivanje koncentracije, aktivnosti i strukture von Willebrandovog faktora}

Von Willebrandova bolest najčešći je nasljedni poremećaj koagulacije u pasa i ljudi (Favaloro, 2011.). Klinički se bolest manifestira krvarenjima u kožu i sluznice, krvarenjima iz nosa te obilnijim krvarenjima nakon operativnih zahvata. Bolest je karakterizirana manjkom von Willebrandovog faktora (vWF), a javlja se $\mathrm{u}$ tri oblika, od bolesti s blagim simptomima (tip 1) do one gdje krvarenja mogu biti letalna (tip 3). Von Willebrandov faktor je glikoprotein koji sintetiziraju megakariociti i endotelne stanice, a ima dvojaku funkciju. Faktor u plazmi služi kao nosač FVIII te ga štiti od proteolize. Druga funkcija očituje se odmah po nastanku oštećenja stijenke krvne žile, vWF lijepi se za oštećenje te priljubljuje trombocite čime počinje primarna hemostaza. Najčešći oblik bolesti je tip 1 u kojem je prisutan djelomični manjak vWF, snižena mu je koncentracija, ali funkcija faktora je uglavnom očuvana. Tip 2 vWB-i karakteriziran je strukturalnim i funkcionalnim defektom vWF-a, a često je kombiniran i s njegovim manjkom (Mannucci i sur., 2009.). U ljudi tip 2 dijeli se u 4 podtipova 2A, 2B, 2M i $2 \mathrm{~N}$, dok u pasa postoji samo podtip 2A koji predstavlja manjak multimera visoke molekularne mase vWFa. Opaža se u njemačkih kratkodlakih i oštrodlakih ptičara. Tip 3 najteži je oblik bolesti, karakteriziran apsolutnim nedostatkom vWF-a u plazmi (<1\%) (Brooks i Catalfamo, 2013.); opaža se u Chesapeake Bay retrivera (Johnson i sur., 1980.), šetlandskih ovčarskih pasa (Raymond i sur., 1990.) te škotskih terijera (Venta i sur., 2000.). 
Sumnju na vWB mogu pobuditi nalazi produljenog BMBV-a i APTV-a te trombocitopenija. Dijagnostika bolesti temelji se na kvantitativnim, funkcionalnim i strukturalnim testovima vWF-a. Prvi korak u dijagnosticiranju je mjerenje koncentracije vWF-a imunokemijskim metodama, najčešće ELISA-om. Između životinjskih vrsti faktor se razlikuje po antigenoj strukturi te je potrebna uporaba vrsno specifičnih ili križno-reaktivnih antitijela. Rezultati kvantitativnog testa uspoređuju se s referentnim vrijednostima za pojedinu vrstu (100\% ili 100 U/mL vWF:Ag), a vrijednosti manje od $50 \%$ (< $50 \mathrm{U} /$ $\mathrm{mL}$ ) ukazuju na deficijenciju von Willebrandovog faktora (Brooks i Catalfamo, 2013.).

Funkcionalnim vWF testom mjeri se sposobnost interakcije vWF-a $\mathrm{s}$ trombocitima, kolagenom ili FVIII. Ristocetin - kofaktor test (vWF:RCo) oslanja se na sposobnost antibiotika ristocetina ili botrocetina - reagensa dobivenog iz zmijskog otrova (Read i sur., 1983.), da potakne konformacijske promjene vWF-a. Iskoristivost vWF:RCo testa na plazmi pasa i mačaka otežana je zbog stvaranja proteinskih precipitata zbog reakcije s ristocetinom. Funkcionalni testovi kojima se mjeri sposobnost vezanja vWF-a na kolagen (vWF:CB) u uporabi su kod ljudi (Favaloro, 2000.) i pasa (Sabino i sur., 2006.). Usporedno se mogu napraviti vWF:Ag i vWF:CB testovi kako bi se razlikovali tip 1 i tip $2 \mathrm{~A}$ vWB-i. Kod tipa 1, vezivanje vWF-a za specifično antitijelo kvantitativno je jednako vezivanju vWF-a za kolagen (jer je vWF funkcionalan), dok je kod tipa 2A omjer vWF:Ag testa i vWF:CB testa veći od 2 (Favaloro, 2011.).

Uzorak za analizu je citratna plazma siromašna trombocitima, a stabilna je svega 4 sata te je analize potrebno napraviti odmah. Također, vWF osjetljiv je na hladnu aktivaciju koja dovodi do znatnog gubitka faktora te je izrazito bitno da se uzorci do analize (maksimalno $4 \mathrm{~h}$ ) čuvaju na sobnoj temperaturi ili da se odmah po uzorkovanju do analize zamrznu i pohrane na $-20{ }^{\circ} \mathrm{C}$ (Funk, 2012.).

\section{Mjerenja funkcija trombocita}

Osnovne funkcije trombocita su agregacija i adhezija, a njihovo in vitro praćenje danas je moguće kroz tri metode mjerenja. Prva pretraga je turbidimetrijska agregometrija trombocita gdje se prati sposobnost sljepljivanja trombocita u prisutnosti određenih spojeva, druga je vrlo slična, no brža je i jednostavnija impedancijska agregometrija, a treća potpuno automatizirana, bez pripreme uzorka, i vrši se na analizatoru funkcije trombocita (npr. PFA-100/200, Dade Behring, SAD).

Turbidimetrijska agregacija trombocita složeni je postupak kojim se ispituje funkcija trombocita i sposobnost stvaranja agregata nakon dodataka različitih agregirajućih sredstava (agonista) od kojih se najčešće koriste: ADP, ristocetin, adrenalin, arahidonska kiselina i kolagen (Baumgarten i sur., 2010.). Testom agregacije trombocita ispituje se postotak porasta transmisije svjetlosti u uzor$\mathrm{ku}$ plazme bogate trombocitima nakon dodatka agregansa (agonista) određene koncentracije. Maksimalnu transmisiju (100\%) posjeduje plazma bez trombocita dok minimalnu transmisiju (0\%) ima plazma bogata trombocitima prije dodatka agonista. Nakon dodatka agregansa plazmi bogatoj trombocitima, dolazi do agregacije trombocita te do porasta transmisije. Rezultati se izražavaju kao postotak agregacije s pojedinim agregirajućim sredstvom, a uz to se obvezno i naznači koncentracija pojedinog agregirajućeg sredstva s kojim je dobiven odgovarajući stupanj (\%) agregacije. Rezultati agregacije trombocita ovisni su, ne samo o funkciji već i o broju trombocita (DyszkiewiczKorpanty i sur., 2005.). Uzorak za analizu 
je puna krv s Na-citratom kao antikoagulansom iz koje se centrifugiranjem (10 - 15 min na 200 - $250 \mathrm{~g}$ na sobnoj temperaturi) priređuje plazma bogata trombocitima. $\mathrm{Za}$ analizu je potreban veliki volumen krvi koja se ne smije ohladiti kako se ne bi aktivirali trombociti. Odvojena plazma stabilna je 3 sata na sobnoj temperaturi (Funk, 2012.). S obzirom na složenost postupka pripreme uzorka i izvođenja pretrage, ona se provodi samo u specijaliziranim laboratorijima, no i dalje se smatra zlatnim standardom agregacijskih metoda (Michelson, 2009., Baumgarten i sur., 2010.).

Impendancijska agregometrija temelji se na promjeni impendance između dviju elektroda nakon agregacije trombocita u kontaktu s određenim agonistom. Sami agonisti i proces agregacije jednaki su kao i kod turbidimetrijske metode, no ovdje je uzorak citratna puna krv što uvelike olakšava i ubrzava analizu. Prednost metode je i bolji prikaz realne in vivo situacije i agregacije. $U$ ispitivanju agregacije trombocita u uzorcima od ovaca (Baumgarten i sur., 2010.) i pasa (Kalbantner i sur., 2010.) dokazano je da je puna krv s hirudinom kao antikoagulansom bolji uzorak od citratne krvi te je primijećeno da svi agonisti koji se koriste u humanoj medicini ne djeluju jednako dobro u različitim životinjskim vrstama.

Analizatori funkcije trombocita (PFA-100/200) omogućuju mjerenje trombocitnih funkcija u uzorku citratne pune krvi. Analizatori su osmišljeni kao POCT (engl. point of care testing) uređaji te se primjenjuju prije svega $u$ probiru, a ne i u dijagnostici. Princip rada instrumenta temelji se na adheziji i agregaciji trombocita oponašanjem in vivo uvjeta fiziološke brzine protoka krvi u arterijama u prisutnosti kolagena i adrenalina (CEPI) te kolagena i ADP-a (CADP), pri čemu se mjeri vrijeme nastanka trombocitnog ugruška (CT) (Miloš i sur., 2006., Michelson, 2009.).
Krajnja točka testa označava vrijeme zgrušavanja (u sekundama) i predstavlja prestanak krvarenja (Brooks i Catalfamo, 2013.). Iako precizniji od BMBV testa, ovakav agregacijski test podložan je predanalitičkim pogreškama poput uporabe neprimjerenog antikoagulansa, aktivacije trombocita tijekom uzorkovanja ili transporta krvi, a često i odgođenim vremenom analize (> 4 sata). Različiti odgovor trombocita pojedinih vrsta životinja na adrenalin ograničava uporabu CEPI spremnika u testiranju. Greška u začepljivanju CEPI membrane, što se očituje kao CT veće od 300 sekundi, zabilježena je u zdravih pasa i konja $\mathrm{s}$ normalnom funkcijom trombocita (Callan i Giger, 2001.). Referentni interval CADP CT testa za pse je od 60 - 120 sekundi (Callan i Giger, 2001.), a u mačaka od 60 - 180 sekundi (Jandrey i sur., 2008.). Produženo vrijeme CADP CT testa odgovara dijagnozi von Willebrandove bolesti ili poremećaja agregacije trombocita. Značajno skraćenje CADP CT utvrđeno je u pasa koji boluju od tipa 1 von Willebrandove bolesti i liječeni su dezmopresinom (Callan i sur., 2005.).

Analiza funkcije trombocita pruža uvid $\mathrm{u}$ poremećaje prokoagulantne aktivnosti trombocita (Brooksi Catalfamo, 2013.). Korištenjem analizatora funkcije trombocita $\mathrm{u}$ pasa $\mathrm{u}$ endotoksičnom šoku opisano je postupno skraćivanje vremena potrebnog za zgrušavanje, unatoč trombocitopeniji (Yilmaz i sur., 2006.), dok je u pasa oboljelih od sepse i sindroma sistemskog upalnog odgovora u prirodnim okolnostima dokazana veća učestalost pojave trombocitnoneutrofilnih agregata (Dircks i sur., 2012.).

\section{Trombocitna antitijela}

Jake trombocitopenije mogu biti posljedica razvoja trombocitnih autoantitijela. Antitijela nastaju kao posljedica prisutnosti različitih stranih tvari u cirkulaciji, a pojedina prepoznaju 
epitope na trombocitima te se vežu na njih. Najčešći uzročnici su lijekovi među kojima prednjače kinini, kinidini, penicilini, vankomicin i trimetoprim/ sulfametoksazol, koji izazivaju izrazito jake trombocitopenije uz krvarenja (petehije, ekhimoze, okultna krvarenja) kao glavni simptom te heparin koji izaziva blažu trombocitopeniju uz trombozu (Arnold i sur., 2013.). $\mathrm{U}$ pasa $\mathrm{s}$ imunoposredovanom trombocitopenijom, broj trombocita je manji od $50000 / \mu \mathrm{L}$, a smatra se da je rizik od spontanog krvarenja izrazito velik kada broj trombocita padne na

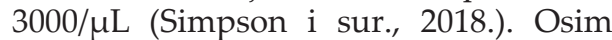
lijekova, antitijela se stvaraju i nakon konzumacije određenih prehrambenih proizvoda ili dodataka prehrani (kravlje mlijeko, orasi, sezam, brusnica), ali i cijepljenja i susreta organizma s različitim mikroorganizmima (erlihije, rikecije, histoplazme i drugi). Koncentracije antitijela prisutne $u$ cirkulaciji neznatne su te se najčešće ne primjećuju problemi, no uporabom nekog lijeka, opetovanom zarazom ili upalom njihov se broj znatno povećava i pokreće se imunološka reakcija. Antitijela se vežu za trombocite te ih na taj način "označavaju“ kao strano tijelo koje je što prije potrebno ukloniti. Dio antitijela, prije svega ona izazvana heparinom, djeluju na aktivaciju i sljepljivanje trombocita te otpuštanje prokoagulantnih spojeva što osim trombocitopenije dovodi i do tromboze (Arnold i sur., 2013.).

U identifikaciji trombocitnih antitijela induciranih lijekovima koriste se varijacije različitih imunoloških testova. Radioimunotest (RIA), ELISA i varijacije ELISA-e mogu izravno detektirati imunoglobuline (Ig) vezane na trombocite te slobodni antitrombocitni Ig u serumu. Osim izravnog mjerenja Ig-a, moguće je mjerenje aktivnosti trombocita, odnosno dostupnog trombocitnog faktora 3 (PF3). Prati se reakcija zgrušavanja nakon dodatka određenog lijeka za koji se sumnja da prouzroči imunološku reakciju, tj. za koji postoje trombocitna antitijela $\mathrm{u}$ organizmu. Pri provođenju PF3 testa, uzorkuje se citratna plazma bogata trombocitima s točno određenim brojem trombocita te se zatim inkubira uz dodatak lijeka koji se smatra uzrokom trombocitopenije. Ako serum pacijenta sadrži imunoglobuline koji se vežu za lijek i za homologne trombocite, trombociti će otpuštati veću količinu PF3 te će se ubrzati stvaranje ugruška u usporedbi s kontrolnim uzorkom (Jain, 1986., Sharma i sur., 2011.). Za detekciju antitijela koristiti se i protočna citometrija koja je u posljednje vrijeme i najčešći odabir. Imunološkim testiranjima pristupa se ovisno o dostupnosti testa i hitnosti slučaja (Arnold i sur., 2013.).

Generalno je mišljenje kako ne postoji jedinstven i pouzdan laboratorijski test za predikciju disfunkcije trombocita. Nužna je provedba nekoliko različitih testova te primjena različitih metoda uz detaljnu anamnezu pacijenta (Sharma i sur., 2011.).

\section{Mjerenja aktivnosti faktora zgrušavanja}

Pretrage mjerenja aktivnosti faktora zgrušavanja zapravo su modificirane pretrage PV-a (za FII, FV, FVII, FX) i APTV-a (za FVIII, FIX, FXI, FXII). Pretrage se provode jednako, ali se koristi modificirana plazma $s$ nedostatkom ciljnog faktora koji želimo izmjeriti. Takvoj komercijalno izmijenjenoj plazmi dodaje se pacijentova plazma te se mjere PV i APTV (Adcock i sur., 2006.). Ukoliko plazma pacijenta sadrži normalne koncentracije funkcionalnog faktora koji ispitujemo, vremena zgrušavanja bit će unutar referentnih vrijednosti za određenu životinjsku vrstu. Aktivnost faktora veća od $50 \%$ znači da nema poremećaja stvaranja fibrina in vivo. Klinička važnost vrijednosti manjih od $50 \%$ ovisi o razmjeru bolesti (krvarenja) 
te koliko faktora zgrušavanja nedostaje (Triplett, 2000.).

$S$ obzirom na to da su faktori zgrušavanja različitih vrsta prisutni u različitim koncentracijama i aktivnostima, a gotove sve vrste (psi, mačke, svinje, kunići, preživači) imaju znatno više vrijednosti od čovjeka, nužna je prilagodba analiza i metoda kada se $u$ mjerenju koristi humana plazma kao dio reagensa. Potrebna je definicija i validacija referentnog raspona za pojedinu životinjsku vrstu i određeni tip reagensa te dilucija uzorka pacijenta (Mischke i Nolte, 1986.). Postoje i kolorimetrijski testovi kojima se može mjeriti prokoagulantna aktivnost nekih faktora, no oni nemaju značenje $u$ veterinarskoj medicini (Collazo i sur., 2013.). Različiti stupnjevi deficita pojedinih faktora koagulacije ustanovljeni su u babeziozi pasa (Barić Rafaj i sur., 2013.), dok su u slučajevima pretilosti aktivnosti bile povećane te ukazivale na prokoagulantni status životinja (Barić Rafaj i sur., 2017.).

\section{Određivanje inhibitora antitrombina $i$ proteina $\mathrm{C}$}

Antitrombin (AT III) i protein C (PC) glavni su fiziološki inhibitori zgrušavanja, sprječavaju spontano započinjanje zgrušavanja i ograničavaju širenje izvan područja ozljede. Antitrombin je protein plazme $s$ višestrukim inhibicijskim djelovanjem unutar sustava zgrušavanja. Inhibicijsko djelovanje antitrombina odnosi se ponajprije na inaktiviranje trombina i FX-a, a zatim i ostalih aktiviranih faktora zgrušavanja. Inhibicijsku aktivnost znatno povećava heparin. Antitrombin je ujedno i najvažniji fiziološki regulator stvaranja fibrina. Stečena deficijencija AT III povezuje se $\mathrm{s}$ diseminiranom intravaskularnom koagulacijom, cirozom i kroničnim bolestima jetre te $\mathrm{s}$ bubrežnim bolestima u kojima se gube proteini (Miloš, 2010., Donahue, 2011.).
Protein C je glikoprotein ovisan o vitaminu $\mathrm{K}$, a sintetizira se $\mathrm{u}$ jetri kao inaktivni zimogen. Fiziološki aktivator PC-a je trombin. Aktivirani protein C (APC) izražava antikoagulacijski i profibrinolitički učinak inaktiviranjem aktiviranih FV i FVIII te neutraliziranjem inhibitora aktivatora plazminogena 1 (PAI-1) (Miloš, 2010.). Deficijencija PC-a ukazuje na lošu prognozu u pasa sa septičnim peritonitisom i zatajenjem jetre, a dobar je pokazatelj kod praćenja terapije portalne hipertenzije. $\mathrm{Uz}$ to, mjerenjem aktivnosti PC-a može se detektirati deficijencija vitamina $\mathrm{K}$ prije pojave kliničkih simptoma koagulopatije (de Laforcade i sur., 2003., 2008., Toulza i sur., 2006.).

Testovi kojima se mjere inhibitori koagulacije su funkcionalni kromogeni testovi kojima se određuje aktivnost inhibitora. Ukoliko je aktivnost smanjena, određuju se i koncentracije PC-a i AT-a III imunokemijskim testovima. Načelo mjerenja AT-a III temelji se na inhibiciji FII-a, dok se metoda detekcije PC-a temelji na aktivaciji plazme specifičnim aktivatorom iz zmijskog otrova pri čemu se mjeri porast apsorbancije na $405 \mathrm{~nm}$. $\mathrm{U}$ provedbi mjerenja koriste se vrsno specifični standardi, a u uporabi su u pacijenata s rizikom od tromboze ili kao biomarkeri funkcije jetre (Toulza i sur., 2006.). Uzorak za analize inhibitora AT III i PC-a je citratna plazma siromašna trombocitima, a stabilna je svega 4 sata te je analize potrebno napraviti odmah. Ukoliko nije moguća analiza unutar 4 sata, plazmu je nužno u što kraćem roku od uzorkovanja odvojiti od stanica te smrznuti i pohraniti na $-20{ }^{\circ} \mathrm{C}$ (Funk, 2012.). Različiti lijekovi mogu utjecati na rezultate obiju pretraga. Heparinska terapija snižava vrijednosti AT-a III, oralna antikoagulacijska terapija utječe na vrijednosti PC-a, a L-asparaginaza smanjuje vrijednosti i AT-a III i PC-a (Miloš, 2010.). 


\section{Kompleksi trombina i antitrombina}

Trombin-antitrombin (TAT) kompleks je molekularni kompleks koji se sastoji od trombina i antitrombina (primarnog inhibitora trombina) u omjeru 1 : 1 (Asakura, 2014.). Kompleks nastaje kao biološki odgovor na stvaranje trombina, a poluvijek života u plazmi je 10 do $15 \mathrm{mi}$ nuta. Povišena koncentracija TAT kompleksa ukazuje na trenutačno prekomjerno stvaranje trombina i služi kao marker za protrombotički status (Adcock i sur., 2006.). Prijašnji podatci o mjerenjima TAT kompleksa u pasa bazirani su na primjeni ELISA metode, $\mathrm{u}$ kojoj su se koristila antitijela na humani trombin (Tsuchiya i sur., 2009., McMichael i sur., 2015.), a danas su dostupni testovi i sa specifičnim antitijelima za pojedine životinjske vrste. Međutim, takve ELISA metode podrazumijevaju analizu većeg broja uzoraka istovremeno što ih čini nepraktičnima za rutinsku upotrebu (Rimpo i sur., 2018.).

Vrijednosti TAT kompleksa mogu biti povišene u starijih ili gravidnih pacijenata, kod akutnog pankreatitisa, multiple traume, akutne i kronične leukemije i raznih bolesti jetre. Vrijednosti su visoke i tijekom heparinske i fibrinolitičke terapije (Adcock i sur., 2006.). Jedno istraživanje dokazalo je korisnost TAT testa kod procjene protrombotičkih stanja u pasa (Ravanat i sur., 1995.), dok je drugo uključivalo TAT kompleks kao marker protromboze $\mathrm{u}$ pasa $\mathrm{s}$ Cushingovim sindromom i dokazalo povišenu razinu TAT kompleksa u pasa oboljelih od malignih tumora (Maruyama i sur., 2005.). Povećane koncentracije TAT kompleksa $\mathrm{u}$ krvi pasa s babeziozom ustvrđene su prije terapije, a one ukazuju na moguću prisutnost subkliničkog DIK-a u babeziozi (Barić Rafaj i sur., 2009.).

Najčešće pogreške javljaju se $u$ predanalitičkim procesima i skupljanju uzorka. Lažno povišene vrijednosti TAT kompleksa dobivaju se pri traumatskoj venepunkciji, prolongiranoj stazi, nedovoljnom miješanju krvi s citratom $u$ epruveti te neadekvatnom centrifugom. Povišene vrijednosti ponekad se nalaze kod pacijenata $\mathrm{s}$ upalom ili $\mathrm{u}$ akutnom stresu te ih je bitno razlučiti od povišenih vrijednosti koje upućuju na koagulacijske poremećaje (Adcock i sur., 2006.).

\section{Razgradni produkti fibrina}

Fibrinoliza je završni korak hemostaze, a laboratorijski je pratimo pomoću razgradnih produkata fibrina koji se oslobađaju degradacijom ugruška. Djelovanjem enzima plazmina fibrinogen te slobodni i umreženi fibrin cijepaju se na međuprodukte velikih molekularnih masa $X$ i $Y$, koji se daljnjom razgradnjom skraćuju na manje fragmente koji se sastoje samo od osnovne D i/ili E domene. Razgradni produkti fibrina ukazuju na aktivaciju plazmina i nisu specifični za razgradnju umreženog fibrina iz ugruška (Stokol i sur., 1999., Adcock i sur., 2006.). Visoki FDP najčešće se veže uz DIK, osobito ako je popraćen visokim PV-om i APTV-om, padom broja trombocita, aktivnosti antitrombina i koncentracije fibrinogena (Stokol i sur., 1999.). Porast FDP-a zabilježen je kod pacijenata s krvarenjima u mozgu, otrovanjem varfarinom, bolestima jetre i bubrega, trombozom, hemolitičkom anemijom, neoplazijama, pankreatitisom te teškom traumom, sepsom i unutarnjim krvarenjem (Boisvert i sur., 2001.).

Serumski FDP testovi (lateks aglutinacija) koriste poliklonska antitijela koja križno reagiraju s cjelovitim fibrinogenom. Test je jednostavan, no smatra se skupim i zahtijeva posebne epruvete te inkubaciju uzorka prije izvedbe (Stokol i sur., 1999.). Plazmatski FDP testovi mogu se koristiti kako bi se zaobišli nedostatci serumskog testa, zahtijevaju jedan uzorak citratne plazme, koriste monoklonska antitijela, relativno su jeftini, a imaju i veću osjetljivost od serumskih testova (Boisvert i sur., 2001.). Lažno pozitivne reakcije zapažene su u zdravih pasa te je test nešto složeniji za izvođenje (Stokol, 1999.). 


\section{D-dimeri}

Najmanji umreženog cirkulaciji djelovanjem plazmina je D-dimer. Koncentracija D-dimera globalni je pokazatelj stvaranja fibrina in vivo i predstavlja izrazito osjetljiv, ali nespecifičan parametar. D-dimeri imaju poluživot od 3 do 6 sati te njima opisujemo trenutnu ili nedavnu fibrinolizu (Adcock i sur., 2006.).

Nalaz visoke koncentracije FDP-a i D-dimera upućuje na pretjeranu fibrinolizu ili drugi oblik poremećaja fibrinolize te je važan dijagnostički pokazatelj kod duboke venske tromboze (DVT), DIK i plućne tromboembolije (PE). Kvantitativno određivanje koncentracije D-dimera važno je u dijagnostici PE-e kod životinja i ljudi (Stokol, 2003.). Temeljem povišene koncentracije D-dimera ne može se pouzdano ustvrditi dijagnoza, ali s obzirom na to da vrijednosti niže od granične vrijednosti isključuju trombozu, D-dimeri imaju visoku negativnu prediktivnu vrijednost. Zbog ovog svojstva najvažnija klinička vrijednost odnosi se na isključivanje prisutnosti DVT ili PE-e. D-dimeri mogu biti povišeni tijekom bilo koje bolesti koja uzrokuje nastajanje i razgradnju fibrina, najčešće u DIK i tromboemboličkim stanjima, iako nisu specifični za njih (Griffin i sur., 2003.). U pasa, D-dimeri su povišeni poslije kirurških zahvata te uslijed imunoposredovane hemolitičke anemije, bolesti jetre i bubrega, zatajenja srca, neoplazija ili unutarnjeg krvarenja (Nelson i Andreasen, 2003.). D-dimeri se koriste kao pomoćni test u kombinaciji $\mathrm{s}$ drugim testovima $\mathrm{u}$ postavljanju dijagnoze te kao test isključivanja DVT-a i PE-a (Herring, 2012.).

Imunološke metode za određivanje koncentracije D-dimera koriste monoklonska antitijela specifična za epitop D-dimera, no analitičkim testovima koje koristimo $\mathrm{u}$ dijagnostici mjere se i koncentracije svih drugih razgradnih pro- dukata koji sadrže taj epitop, ne samo najmanji fragment (Stokol, 2003.). Testovi kao uzorak koriste citratnu plazmu siromašnu trombocitima, a dostupne metode uključuju aglutinacijske testove (lateks aglutinacija i hemaglutinacija), enzimimunokemijske testove (ELISA, imunofiltracija) te lateks imunoturbidimetriju, a prilagođeni su automatskim analizatorima (Stokol, 2003., Adcock i sur., 2006.). Svim metodama smetaju lipemija, povećana viskoznost uzorka i povećani broj trombocita, dok su neosjetljive na hemolizu (osim imunoturbidimetrije) i bilirubinemiju. Glavni problem i nedostatak pretrage je odsustvo jedinstvenih referentnih intervala, za svaku od metoda i svaku kombinaciju reagenasa nužno je definirati interval te postaviti vrijednost za isključivanje (Adcock i sur., 2006.).

$S$ obzirom na složenost koagulacijskog sustava te velik izbor pretraga, laboratorijsko ispitivanje poremećaja hemostaze potrebno je pomno isplanirati. Preporuka je provesti više stupnjeva detekcije, počevši od nekoliko najčešćih globalnih pretraga te barem jedne specifične. Specifične pretrage razlikuju se po složenosti izvođenja, cijeni i dostupnosti, no pravilnim kombiniranjem moguće je detektirati gotovo sve poremećaje, čak i bez korištenja svih specifičnih pretraga definiranih za određeni poremećaj. Važno je naglasiti da ne postoji jedinstveni test koji samostalno daje uvid u funkciju cjelokupnog sustava zgrušavanja.

\section{Literatura}

1. ADCOCK, D. M., M. A. BETHEL and P. A. MACY (2006): Coagulation Handbook. Esoterix. Austin, Texas.

2. AO, H., J. K. MOON, M. TASHIRO and H. TERASAKI (2001): Delayed platelet dysfunction in prolonged induced canine hypothermia. Resuscitation 51, 83-90.

3. ARNOLD, D. M., I. NAZI, T. E. WARKENTIN J. W. SMITH, L. J. TOLTL, J. N. GEORGE and J. G. KELTON (2013): Approach to the diagnosis and management of drug-induced immune thrombocytopenia. Transfus. Med. Rev. 27, 137-145. 
4. ASAKURA, H. (2014): Pathophysiology and classification of thrombosis. Nihon Rinsho 72, 11841190. (In Japanese).

5. BARIĆ RAFAJ, R., V. MATIJATKO, I. KIŠ, N. KUČER, T. ŽIVIČNJAK, N. LEMO, Z. ŽVORC, M. BRKLJAČIĆ and V. MRLJAK (2009): Alterations in some blood coagulation parameters in naturally occurring cases of canine babesiosis. Acta Vet. Hung. 57, 295-304.

6. BARIĆ RAFAJ, R., J. KULEŠ, A. TVARIJONAVICIUTE, J. CERON, Ž. MIHALJEVIĆ, A. TUMPA and V. MRLJAK (2017): Plasma markers of inflammation and hemostatic and endothelial activity in naturally overweight and obese dogs. BMC Vet. Res. 13:13.

7. BARIĆ RAFAJ, R., J. KULEŠ, J. SELANEC, N. VRKIĆ, V. ZOVKO, M. ZUPANČIĆ, A. TRAMPUŚ BAKIJA, V. MATIJATKO, M. CRNOGAJ and V. MRLJAK (2013): Markers of Coagulation Activation, Endothelial Stimulation, and Inflammation in Dogs with Babesiosis. J. Vet. Intern. Med. 27, 1172-1178.

8. BAUMGARTEN, A., M. WILHELMI, K. KALBANTNER, M. GANTER and R. MISCHKE (2010): Measurement of platelet aggregation in ovine blood using a new impedance aggregometer. Vet. Clin. Path. 39, 149-156.

9. BHASKAR, A. (2016): Cell based model of haemostasis. CMI 14, 53-58.

10. BOISVERT, A. M., C. L. SWENSON and C. J. HAINES (2001): Serum and plasma latex agglutination tests for detection of fibrin(ogen) degradation products in clinically ill dogs. Vet. Clin. Pathol. 30, 133-136.

11. BRIGGS, C., P. HARRISON and S. J. MACHIN (2007): Continuing developments with the automated platelet count. Int. J. Lab. Hem. 29, 77-91.

12. BRIGGS, C. and S. J. MACHIN (2012): Automated platelet analysis. In: Kottke-Marchant K, Davis BH. Laboratory hematology practice. Blackwell Publishing Ltd.

13. BROOKS, M. B. and J. L. CATALFAMO (2013): Current diagnostic trends in coagulation disorders among dogs and cats. Vet. Clin. Small Anim. Elsevier Inc, 7.

14. BROOKS, M. B., T. STOKOL and J. L. CATALFAMO (2011): Comparative hemostasis: Animal Models and New Hemostasis Tests. Clin. Lab. Med. 31, 139159.

15. CALLAN, M. B. and U. GIGER (2001): Assessment of point-of-care instrument for identification of primary hemostatic disorders in dogs. Am. J. Vet. Res. 62, 652-658.

16. CALLAN, M. B., U. GIGER and J. L. CATALFAMO (2005): Effect of desmopressin on von Willebrand factor multimers in Doberman Pinschers with type 1 von Willebrand disease. Am. J. Vet. Res. 66, 861867.

17. COLLAZO, V., C. ALONSO and G. FRUTOS (2013): Validation of an automated chromogenic assay of potenncy of factor VIII in commercial concentrates. Int. J. Lab. Hematol. 35, 38-45.

18. COUTO, C. G. (2014): Disorders of hemostasis: clinical approach to the bleeding patient. In: Nelson, R. and Couto, C. G., eds.: Small Animal Internal Medicine, $5^{\text {th }}$ ed. Mosby, St Louis, 1246.

19. DE LAFORCADE, A. M., L. M. FREEMAN, S. P. SHAW, M. B. BROOKS, E. A. ROZANSKI and J.
E. RUSH (2003): Hemostatic changes in dogs with naturally occurring sepsis. J. Vet. Intern. Med. 17, 674-679.

20. DE LAFORCADE, A. M., E. A. ROZANSKI, L. M. FREEMAN and W. LI (2008): Serial evaluation of protein $\mathrm{C}$ and antithrombin in dogs with sepsis. J. Vet. Intern. Med. 22, 26-30.

21. DIRCKS, B. H., R. MISCHKE and H. J. SCHUBERTH (2012): Platelet- neutrophil aggregate formation in blood samples from dogs with systemic inflammatory disorders. Am. J. Vet. Res. 73, 939-945.

22. DONAHUE, S. M., M. BROOKS and C. M. OTTO (2011): Examination of hemostatic parameters to detect hypercoagulability in dogs with severe protein-losing nephropathy. J. Vet. Emrg. Crit. Car. 21, 346-355.

23. DUDEK, M. M., N. KENT, K. M. GUSTAFSSON, T. L. LINDAHL and A. J. KILLARD (2011): Fluorescence-based blood coagulation assay device for measuring activated partial thromboplastin time. Anal. Chem. 83, 319-328.

24. DYSZKIEWICZ-KORPANTY, A. M., E. P. FRENKEL and R. SARODE (2005): Approach to the assessment of platelet function: comparison between optical-based platelet-rich plasma and impedance-based whole blood platelet aggregation methods. Clin. Appl. Thromb-Hem. 11, 25-35.

25. FAVALORO, E. J. (2000): Collagen binding assay for von Willebrand factor (VWF: CBA): detection of von Willebrands disease (VWD), and discrimination of VWF subtypes, depends on collagen source. Thromb. Haemost. 83, 127-135.

26. FAVALORO, E. J. (2011): Diagnosis and classification of von Willebrand disease: a review of differential utility of various functional von Willebrand factor assays. Blood Coagul. Fibrinolysis. 22, 553-564.

27. FUNK, D. M. A., G. LIPPI, and E. J. FAVALORO (2012): Quality standards for sample processing, transportation, and storage in hemostasis testing. Semin. Thromb. Hemost. 38, 576-585.

28. GRANAT, F., A. GEFFRE, J. P. BRAUN and C. TRUMEL (2011): Comparison of platelet clumping and complete blood count result with Sysmex XT$2000 \mathrm{iV}$ in feline blood sampled on EDTA or EDTA plus CTAD (citrate, theophylline, adenosine and dipyridamole). J. Fel. Med. Surg. 13, 953-958.

29. GRIFFIN, A., M. B. CALLAN, F. S. SHOFER and U. GIGER (2003): Evaluation of a canine D-dimer pointof-care test kit for use in samples obtained from dogs with disseminated intravascular coagulation, thromboembolic disease, and hemorrhage. Am. J. Vet. Res. 64, 1562-1569.

30. HERRING, J. (2012): Diagnostic approach to small animal bleeding disorders. Top Companion Anim. Med. 27, 76-78.

31. JAIN, N. C. (1986): Schalm's Veterinary Hematology, $4^{\text {th }}$ ed. Lea and Febiger, Philadelphia (20-86).

32. JANDREY, K. E., J. W. NORRIS, K. A. MACDONALD, M. D. KITTLESON and F. TABLIN (2008): Platelet function in clinically healthy cats and cats with hypertrophic cardiomyopathy: analysis using the platelet function analyzer- 100 Vet. Clin. Pathol. 37, 385-388.

33. JOHNSON, G. S., G. E. LEES, R. E. BENSON, T. K. ROSBOROUGH and W. J. DODDS (1980): A bleeding disease (von Willebrand's disease) in a 
Chesapeake Bay Retriever. J. Am. Vet. Med. Assoc. 176, 1261-1263.

34. KALBANTNER, K., A. BAUMGARTEN and R. MISCHKE (2010): Measurement of platelet function in dogs using a novel impedance aggregometer. Vet. J. 185, 144-151.

35. KITCHEN, S. and M. MAKRIS (2009): Laboratory tests of hemostasis. Practical hemostasis and thrombosis. 2. ed. West Sussex: Wiley-Blackwell. Pp. 7-16.

36. KUNICKA, J. E., G. FISCHER, J. MURPHY and D. ZELMANOVIC (2000): Improved platelet counting using two-dimensional laser light scatter. Am. J. Clin. Pathol. 114, 283-289.

37. MALleTT, S. V. and D. J. COX (1992): Thrombelastography. Br. J. Anaesth. 69, 307-313.

38. MANNUCCI, P. M., A. B. FEDERICI, A. H. JAMES and C. M. KESSLER (2009): von Willebrand disease in the $21^{\text {st }}$ century: current approaches and new challenges. Haemophilia 15, 1154-1158.

39. MARUYAMA, H., T. WATARI, T. MIURA, M SAKAI, T. TAKAHASHI, H. KOIE, Y. YAMAYA, K. ASANO, K. EDAMURA, T. SATO, S. TANAKA, A. HASEGAWA and M. TOKURIKI (2005): Plasma thrombinantithrombin complex concentrations in dogs with malignant tumours. Vet. Rec. 156, 839-840.

40. MCMICHAEL, M., M. O'BRIEN and S. A SMITH (2015): Hypercoagulability in Dogs with Blastomycosis. J. Vet. Intern. Med. 29, 499-504.

41. MICHELSON, A. D. (2009): Methods for the measurement of platelet function. Am. J. Cardiol. 103, 20A-26A.

42. MILOŠ, M. (2010): Laboratorijska dijagnostika u hemostazi. U: Zadro, R.: Koagulacija, Priručnik za trajno usavršavanje Hrvatske komore medicinskih biokemičara. Medicinska naklada, Zagreb (11-19).

43. MILOŠ, M., D. C. HERAK and R. ZADRO (2006): Laboratory evaluation of primary hemostasis on a PFA-100 platelet function analyzer. 5. hrvatski kongres medicinskih biokemičara.

44. MISCHKE, R. (2017): Laboratory evaluation and interpretation of haemostasis in small animals. J. Hellenic Vet. Med. Soc. 65, 165-180.

45. MISCHKE, R. and I. J. A. NOLTE (1986): Hemostasis: Introduction, Overview, Laboratory Techniques. In: Schalm's Veterinary hematology, $4^{\text {th }}$ ed. Lea and Febiger, Philadelphia (519-525).

46. NELSON, O. L. and C. ANDREASEN (2003): The utility of plasma D-dimer to identify thromboembolic disease in dogs. J. Vet. Intern. Med. 17, 830-834.

47. NIKOLAC, N., V. Š. SMOLČIĆ, A. M. ŠIMUNDIĆ i I. ĆELAP (2012): Hrvatsko društvo za medicinsku biokemiju i laboratorijsku medicinu: Nacionalne preporuke za uzorkovanje venske krvi. Ann. Lab. Med. 32, 250-256

48. OTTO, C. M., T. M. RIESER, M. B. BROOKS and M. W. RUSSELL (2000): Evidence of hypercoagulability in dogs with parvoviral enteritis. J. Am. Vet. Med. Assoc. 217, 1500-1504.

49. OWREN, P. A. (1959): Thrombotest: A new method for controling anticoagulant therapy. Lancet 2, 754-758.

50. PAYNE, B. A. (1985): EDTA-induced pseudothrombocytopenia: recognizing a laboratory artifact. Postgrad. Med. 77, 75-76.

51. RAVANAT, C., M. FREUND, F. DOL, Y. CADROY, J. ROUSSI, F. INCARDONA, J. P. MAFFRAND, B BONEU, L. DROUET and C. LEGRAND (1995):
Cross-reactivity of human molecular markers for detection of prethrombotic states in various animal species. Blood Coagul. Fibrin. 6, 446-455.

52. RAYMOND, S. L., D. W. JONES, M. B. BROOKS and W. J. DODDS (1990): Clinical and laboratory features of a severe form of von Willebrand disease in Shetland sheepdogs. J. Am. Vet. Med. Assoc. 197, 1342-1346.

53. READ, M. S., J. Y. POTTER and K. M. BRINKHOUS (1983): Venom coagglutinin for detection of von Willebrand factor activity in animal plasmas. J. Lab. Clin. Med. 101, 74-82.

54. RIMPO, K., A. TANAKA, M. UKAI, Y. ISHIKAWA M. HIRABAYASHI and T. SHOYAMA (2018): Thrombin - antithrombin complex measurement using a point-of-care testing device for diagnosis of disseminated intravascular coagulation in dogs. Plos ONE 13, e020551.

55. ROZANSKI, E., K. J. DROBATZ, D. HUGHER, M. SCOTTI and U. GIGER. (1999): Thrombotest (PIVKA) Test Results in 25 Dogs with Acquired and Hereditary Caogulopathies. J. Vet. Emerg. Crit. Care 9, 73-78.

56. RUOTSALO, K. and S. T. MARGO (2009): Coagulation Tests. Lifelearn Inc.

57. SABINO, E. P., H. N. ERB and J. L. CATALFAMO (2006): Development of a collagen-binfing activity assay as a screening test for type II von Willebrand disease in dogs. Am. J. Vet. Res. 67, 242-249.

58. SEE, A. M., K. L. SWINDELLS, M. J. SHARMAN, K. L. HAACK, D. GOODMAN, A. DELAPORTA, I ROBERTSON and S. F. FOSTER (2009): Activated coagulation times in normal cats and dogs using MAX-ACTTM tubes. Aust. Vet. J. 87, 292-295.

59. SHARMA, P., R. KAR, R. BHARGAVA, R. RANJAN, P. C. MISHRA and R. SAXENA (2011): Acquired platelet dysfunction in 109 patients from a tertiary care referral hospital. Clin. Appl. ThrombHem. 17, 88-93.

60. SIMPSON, K., P. CHAPMAN and A. KLAG (2018): Long-term outcome of primary immune-mediated thrombocytopenia in dogs. J. Small. Anim. Pract. 59, 674-680.

61. STOKOL, T. (2003): Plasma D-dimer for the diagnosis of thromboembolic disorders in dogs. Vet. Clin. North. Am. Small. Anim. Pract. 33, 1419-1435.

62. STOKOL, T., M. B. BROOKS, H. ERB and G. E. MAULDIN (1999): Evaluation of kits for the detection of fibrin(ogen) degradation products in dogs. J. Vet. Intern. Med. 13, 478-484.

63. TASKER, S., P. J. CRIPPS and A. J. MACKIN (1999): Estimation of platelet counts on feline blood smears. Vet. Clin. Pathol. 28, 42-45.

64. TRIPLETT, D. A. (2000): Coagulation and bleeding disorders: review and update. Clin. Chem. 46, 1260-1269.

65. TSUCHIYA, R., Y. AKUTSU, A. IKEGAMI, M. SCOTT, S. NEO, T. ISHIKAWA, M. HISASUE and T. YAMADA (2009): Prothrombotic and inflammatory effects of intravenous administration of human immunoglobulin $\mathrm{G}$ in dogs. J. Vet. Intern. Med. 23, 1164-1169.

66. TOULZA, O., S. A. CENTER, M. B. BROOKS, H. N. ERB, K. L. WARNER and W. DEAL (2006): Evaluation of plasma protein $\mathrm{C}$ activity for detection of hepatobiliary disease and portosystemic shunting in dogs. J. Am. Vet. Med. A. 229, 1761-1771.

67. VENTA, P. J., J. LI, V. YUZBASIYAN-GURKAN, G. J. BREWER and W. D. SCHALL (2000): Mutation 
causing von Willebrand's disease in Scottish Terriers. J. Vet. Intern. Med. 14, 10-19.

68. WIINBERG, B., A. L. JENSEN, R. ROJKJAER, P. JOHANSSON, M. KJELGAARD-HANSEN and A. T. KRISTENSEN (2005): Validation of human recombinant tissue factor-activated thromboelastography on citrated whole blood from clinically healthy dogs. Vet. Clin. Pathol. 34, 389-393.

69. YILMAZ, Z., Y. O. ILLCOL, S. TORUN and I. H. ULUS (2006): Inravenous administration of choline or CDP-choline improves platelet count and platelet closure times in endotoxin-treated dogs. Shock 25, 73-79.

\section{Coagulation assays in veterinary medicine}

Andrea TUMPA, mag. med. biochem., Assistant, Renata BARIĆ RAFAJ, BSc, PhD, Full Professor, Faculty of Veterinary Medicine University of Zagreb, Croatia

Haemostasis is the process of stopping bleeding. Spontaneous haemostasis includes complex biochemical mechanisms of blood clotting, regulated interactions between injured tissue, blood vessels and circulating thrombocytes, procoagulants, anticoagulants, and fibrinolytic proteins. Haemostasis is dividedintothreephases: primary haemostasis, secondary haemostasis, and fibrinolysis. Nonfunctional primary haemostasis results in the slow and difficult formation of a platelet clot. In the event of an injury, blood will be released from the blood vessels for a few seconds or minutes until a stable secondary haemostatic clot is formed. In the case of nonfunctional secondary haemostasis, bleeding is not observed immediately, but after a few minutes. Given the different stages of haemostasis and various activation pathways, different laboratory measurement methods have been developed. This study outlines and describes the coagulation tests currently applied in veterinary practice. The method and the purpose of each test are described, along with major remarks regarding sampling and possible interferences. Blood sampling for coagulation tests is more sensitive than sampling for other blood analyses. It is essential to avoid platelet activation and for this reason, ideal sampling would be venepuncture without venous stasis. Most coagulation assays use platelet-poor plasma as a sample. The vast majority of haemostasis measurements include monitoring clot formation (coagulum), i.e. monitoring the speed and ability or lack of ability to form a blood clot. Today, methods are automated and the time of the clot formation is measured by electro-mechanical or photo-optical methods. Additionally, it is possible to measure the activity of enzymes and coagulation inhibitors, and the concentration of individual components of coagulation cascades and fibrinolysis. In these cases, immunochemical methodsbased on the specific antigen-antibody reaction are used. Thromboelastography is a relatively new method that is increasingly used. In contrast to standard coagulation tests, thromboelastography uses whole blood as a sample. This method evaluates the kinetics of the entire clotting process from the initial formation of the clot, through polymerization of fibrin, to the final step of the formation of the stable secondary clot. Laboratory diagnostics begins with the global coagulation assays. Global coagulation assays are the simplest and they cover both the intrinsic and extrinsic pathway. Assays that are included are bleeding time, prothrombin time, activated partial thrombolytic time, thrombin time, platelet count, and fibrinogen. To set a definitive diagnosis, it is necessary to perform one or more specific coagulation tests. Specific tests include the analysis of activity and function of platelets, platelet antibodies, and measurement of the concentration and activity of von Willebrand factor and clotting inhibitors (antithrombin and protein C). It is also possible to follow the course of fibrinolysis by measuring the concentration of fibrin and fibrinogen degradation products. Due to the complexity of the coagulation system, laboratory testing of haemostasis needs to be carried out in several stages, starting from several global assays and at least one specific. It is important to emphasize that there is no single test that can independently provide insight into the function of the entire coagulation system.

Key words: haemostasis; coagulation; platelets; global coagulation assays; thrombocytopenia 